\section{Removal of Lipophilic Extractives from Paper Pulp by Laccase and Lignin-Derived Phenols as Natural Mediators}

ANA GUTIÉRREZ, ${ }^{*},{ }^{\dagger}$ JORGE RENCORET, ${ }^{\dagger}$ DAVID IBARRA, ${ }^{\ddagger}$ SETEFILLA MOLINA, ${ }^{\dagger}$ SUSANA CAMARERO, ${ }^{\ddagger}$ JAVIER ROMERO, $\$$ JOSÉ C. DEL RÍO, ${ }^{\dagger}$ AND

ÁNGEL T. MARTÍ NEZ

Instituto de Recursos Naturales y Agrobiología de Sevilla, CSIC, PO Box 1052, E-41080 Seville, Spain, Centro de Investigaciones Biológicas, CSIC, Ramiro de Maeztu 9, E-28040 Madrid, Spain, and Centro de Investigación y Tecnología, ENCE, Carretera de Campañó, Ribeiro Vao, E-36157 Pontevedra, Spain

In this paper, we show for the first time that ligninderived phenols can act as laccase mediators for the removal of lipophilic compounds from paper pulp. These natural mediators represent an alternative to synthetic mediators, such as 1-hydroxybenzotriazole (HBT), that cause some economic and environmental concerns. Unbleached kraft pulp from eucalypt wood, which contained free and conjugated sterols responsible for pitch deposition in the manufacture of totally chlorine free paper, was treated with a fungal laccase in the presence of syringaldehyde, acetosyringone, and $p$-coumaric acid as mediators. The composition of lipophilic extractives in the pulps after the enzymatic treatment followed by a hydrogen peroxide stage was analyzed by gas chromatography and gas chromatography/mass spectrometry. The enzymatic treatment using syringaldehyde as laccase mediator caused the highest removal (over 90\%) of free and conjugated sitosterol, similar to that attained with HBT, followed by acetosyringone (over $60 \%$ removal), whereas $p$-coumaric acid was barely effective. Moreover, recalcitrant oxidized steroids surviving laccase-HBT treatment could be removed when using these natural mediators. Pulp brightness was also improved (from $57 \%$ to $66 \%$ ISO brightness) by the laccase treatment in the presence of the above phenols followed by the peroxide stage due to the simultaneous removal of lignin.

\section{Introduction}

The so-called pitch deposits formed during pulping and papermaking drastically reduce the quality of the final product, negatively affect the runnability of the paper machine, and are responsible for shutdowns of mill operations, resulting in significant economical losses in this industrial sector (1). Pitch deposits have their origin in the lipophilic components of the raw material (wood) that survive

\footnotetext{
* Corresponding author phone: 34 954624711; fax: 34 954624002; e-mail: anagu@irnase.csic.es.

† Instituto de Recursos Naturales y Agrobiología de Sevilla, CSIC.

‡ Centro de Investigaciones Biológicas, CSIC.

$\S$ Centro de Investigación y Tecnología, ENCE.
}

the pulping and/or bleaching processes. Pitch problems have been aggravated with the introduction of more environmentally friendly practices such as the reduction in water usage (and effluent discharge) and the introduction of totally chlorine free (TCF) bleaching using combinations of nonchlorine oxidizing chemicals. Unfortunately, oxygen and hydrogen peroxide used in TCF sequences are not as effective as chlorine reagents, such as chlorine dioxide, neither in removing these lipophilic compounds nor in bleaching pulps.

As an alternative to physicochemical treatments that are not fully satisfactory, biological methods have been developed in the last few years for pitch control, based on the use of microorganisms or their enzymes (2). Lipases have been successfully applied to softwood mechanical pulping at mill scale (3). This technology has wide use in pulp and paper mills in Japan, and some mills in North America and China have also adopted it. These enzymes hydrolyzing triglycerides are being used by mills producing mechanical pulp from some raw materials, mainly pine. However, pitch problems in most of the chemical and mechanical processes using other raw materials have not been solved yet. This fact has driven the search for new enzymes to solve the problems caused by other lipophilic compounds, including free and conjugated sterols, in addition to triglycerides.

The use of enzymes of the group of laccases (EC 1.10.3.2) in the presence of compounds acting as redox mediators has already been described for the bleaching of different paper pulps, and very recently the authors showed that it can be also successfully applied for the removal of the lipophilic extractives responsible for pitch deposition $(4,5)$. In these previous studies the synthetic compound 1-hydroxybenzotriazole (HBT) was used as laccase mediator. Since some issues concerning the use of this and related synthetic mediators (such as the high cost and possible toxicity) hinder its industrial application, the search for natural compounds that could act as laccase mediators has been considered (6, 7). In the present paper three phenolic compounds related to lignin, namely $p$-coumaric acid, syringaldehyde, and acetosyringone, are investigated as laccase mediators for the enzymatic removal of pulp lipids causing pitch deposits. The use of natural compounds as laccase mediators makes this enzymatic treatment more feasible to be applied in the pulp and paper industry.

\section{Materials and Methods}

Eucalypt Pulp and Black Liquor. Eucalyptus globulus unbleached kraft pulp, with a kappa number of 15.8, a brightness of $36.7 \%$ ISO, and an intrinsic viscosity of 1239 $\mathrm{mL} / \mathrm{g}$; and black liquor were obtained from the ENCE mill in Pontevedra (Spain).

Fungal Laccase and Mediators. The laccase preparation was provided by Beldem (Andenne, Belgium), and included a major protein of $70 \mathrm{kDa}$ ( $>99 \%$ after sodium dodecyl sulfate/ polyacrylamide gel electrophoresis) with laccase activity. No esterase activity was detected in the enzyme preparation. The enzyme was obtained from fermentor cultures of a laccase-hyperproducing strain of the fungus Pycnoporus cinnabarinus (8) grown as described by Lomascolo et al. (9). Its biochemical characteristics have been described previously (10). Activity was measured by oxidation of $5 \mathrm{mM} \mathrm{2,2'-}$ azino-bis(3-ethylbenzothiazoline-6-sulfonic acid) (ABTS) to its cation radical $\left(\epsilon_{436} 29300 \mathrm{M}^{-1} \mathrm{~cm}^{-1}\right)$ in $0.1 \mathrm{M}$ sodium acetate (pH 5) at $24{ }^{\circ} \mathrm{C}$. One activity unit was defined as the amount of enzyme transforming $1 \mu \mathrm{mol}$ of ABTS per min. Syringaldehyde (4-hydroxy-3,5-dimethoxybenzaldehyde), acetosyringone (4-hydroxy-3,5-dimethoxyphenylethanone), and 

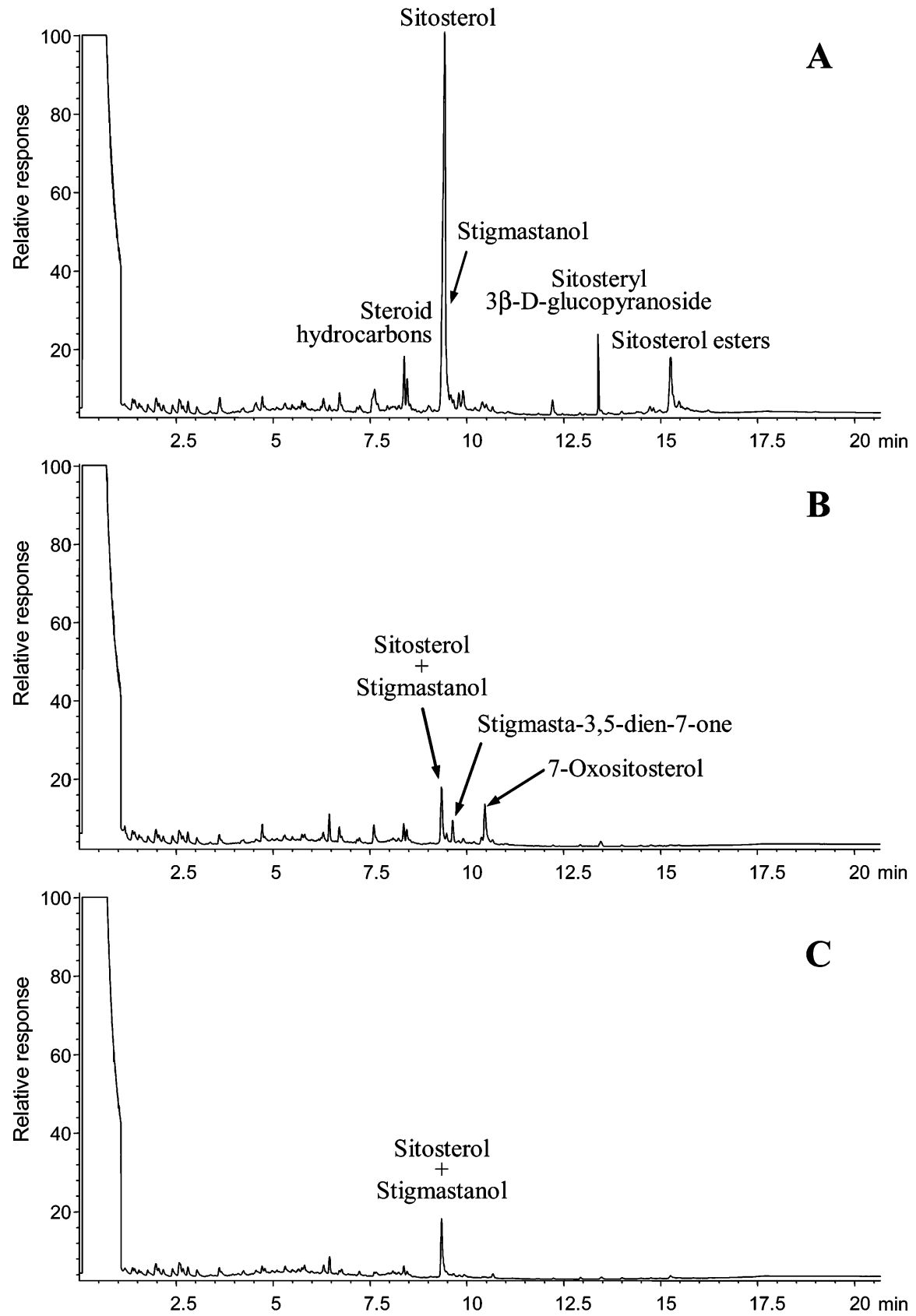

FIGURE 1. GC analysis of lipophilic extractives (as trimethylsilyl ether derivatives) during eucalypt pulp treatment with laccase-mediator followed by peroxide treatment: (A) control pulp after $\mathrm{H}_{2} \mathrm{O}_{2}$ bleaching; (B) pulp after treatment with laccase in the presence of $\mathrm{HBT}$, and subsequent $\mathrm{H}_{2} \mathrm{O}_{2}$ stage; and (C) pulp after treatment with laccase in the presence of syringaldehyde, and subsequent $\mathrm{H}_{2} \mathrm{O}_{2}$ stage. All chromatograms correspond to the same amount of pulp.

p-coumaric acid (3-(4-hydroxyphenyl)-2-propenoic acid) were assayed as mediators, and compared with HBT.

Laccase-Mediator Treatments. Pulp treatments with laccase-mediator were carried out in duplicate using $10 \mathrm{~g}$ (dry weight) of pulp at $3 \%$ consistency (w:w) in 50 mM sodium tartrate (pH 4), $200 \mathrm{U}$ of laccase, $6.75 \mathrm{mM}$ concentration of syringaldehyde, acetosyringone, and $p$-coumaric acid according to previous results (6), and $3.33 \mathrm{mM}$ of HBT (all from Sigma-Aldrich). The treatments were carried out in 500-mL flasks with $\mathrm{O}_{2}$ bubbling, placed in a thermostatic shaker at $170 \mathrm{rev} / \mathrm{min}$ and $50{ }^{\circ} \mathrm{C}$, for $12 \mathrm{~h}$. In a subsequent step, pulps at $5 \%$ consistency (w:w) were submitted to $(i)$ an alkaline extraction stage using $1.5 \% \mathrm{NaOH}$ (w:w) referred to pulp dry weight at $60{ }^{\circ} \mathrm{C}$ for $1 \mathrm{~h}$; or (ii) a bleaching stage using $3 \%$ (w:w) $\mathrm{H}_{2} \mathrm{O}_{2}$ and $1.5 \%$ (w:w) $\mathrm{NaOH}$, both referred to pulp dry weight, at $90{ }^{\circ} \mathrm{C}$ for $2 \mathrm{~h}$. Controls including laccase without mediator, mediator alone, and denaturized laccase (after 30 min at $100^{\circ} \mathrm{C}$ ) were also performed.

Lipid Extraction from Pulps. Pulps were air-dried ( $40{ }^{\circ} \mathrm{C}$ until constant weight) and samples were Soxhletextracted with acetone for $8 \mathrm{~h}$ (11). All extracts were evaporated to dryness and redissolved in chloroform for analysis of the lipophilic fraction by gas chromatography (GC) and gas chromatography/mass spectrometry (GC/MS).

Fractionation by Solid-Phase Extraction (SPE). Samples of the lipophilic extracts from pulp after the laccase treatment followed by the peroxide treatment (and controls) were fractionated by SPE $(12,13)$ using aminopropyl-phase cartridges $(500 \mathrm{mg})$ from Waters. The extracts were taken up in a minimal volume $(<0.5 \mathrm{~mL})$ of hexane/chloroform $(4: 1)$ and loaded into the cartridge previously conditioned with 
<smiles>CCC(CCC(C)C1CCC2C3CC=C4CC(O)CCC4(C)C3CCC12C)C(C)C</smiles>

I<smiles>CCC(CCC(C)C1CCC2C3CCC4CC(=O)CCC4(C)C3CCC12C)C(C)C</smiles>

IV<smiles>CCC(C)CCC(C)C1CCC2C1CCC1C2CCC2CC(O)CCC21C</smiles>

II<smiles>C/C=C(/CC)C(C)CCC1CCC2C1CCC1C2CC=C2CC(O)CCC21C</smiles>

III<smiles>CCC(C)CCC1CCC2C(C(C)C)CCC3C(C(=O)C=C4C=CCCC43C)C12</smiles>

V<smiles>CCC(C)CCC(C)C1CCC2C1CCC1C2C(O)C=C2CC(O)CCC21C</smiles>

VI<smiles>CCC(CCC(C)C1CCC2C3C(O)C=C4CC(O)CCC4(C)C3CCC12C)C(C)C</smiles>

VII<smiles>CCC(C)CCC(C)C1CCC2C3CC(O)C4(O)CC(O)CCC4(C)C3CCC12C</smiles>

VIII<smiles>CCC(CC)C(C)CCC1CCC2C3C(=O)C=C4CC(O)CCC4(C)C3CCC12C</smiles>

IX

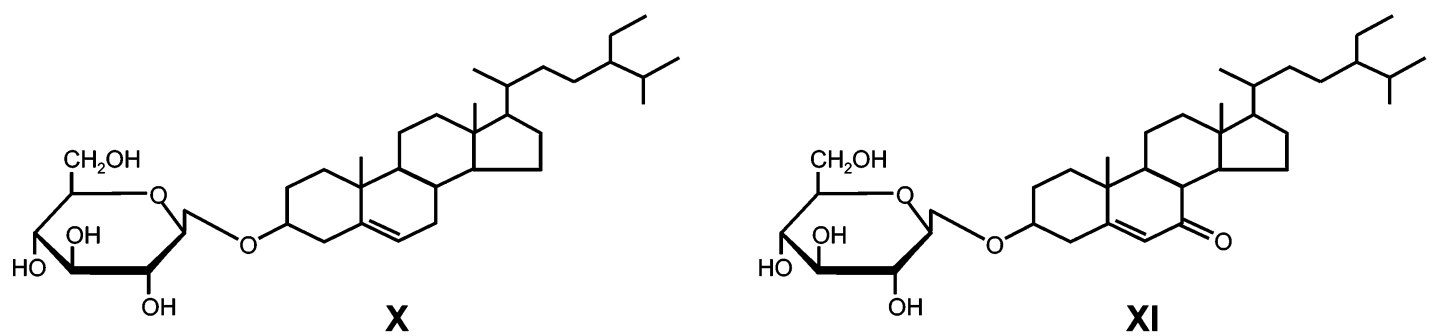

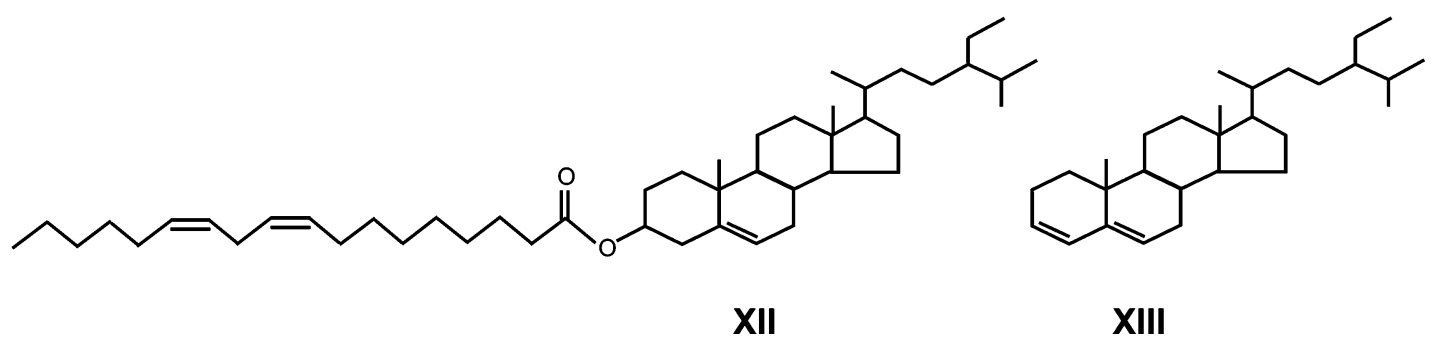

FIGURE 2. Chemical structures of the main lipophilic extractives found in eucalypt kraft pulp. See Table 1 for names and relative abundances (structures XII and XIII correspond to sitosteryl linoleate and stigmasta-3,5-diene, respectively).

hexane ( $4 \mathrm{~mL})$. The fraction containing sterol esters was eluted by gravity with $8 \mathrm{~mL}$ of hexane.

Saponification of Sterol Esters. The SPE fractions, from laccase-treated and control pulp, containing sterol esters were dried under nitrogen and hydrolyzed by refluxing them with $0.5 \mathrm{M}$ potassium hydroxide in $90 \%$ ethanol for $8 \mathrm{~h}$. The solutions were then acidified with $6 \mathrm{M}$ hydrochloric acid and thoroughly extracted with hexane, dried over anhydrous sodium sulfate, and the solvent was removed in a rotary evaporator. Both free sterols and fatty acids were analyzed by GC and GC/MS.
GC and GC/MS Analyses of the Lipophilic Extracts. The whole extractives from pulps, as well as the saponified sterol esters from SPE, were analyzed by GC and GC/MS using short and medium-length high-temperature capillary columns as previously described (13). Bis(trimethylsilyl)trifluoroacetamide (BSTFA) silylation, in the presence of pyridine, was used when required.

Pulp Evaluation. Pulp brightness, kappa number, and intrinsic viscosity were analyzed following ISO 3688:1999, ISO 302:1981, and ISO 5351/1:1981 standard methods, respectively (14). 
TABLE 1. Composition of Lipophilic Extractives from Eucalypt Pulp Treated with Laccase in the Presence and Absence of Different Mediators, Followed by a $\mathrm{H}_{2} \mathrm{O}_{2}$ Stage, and Control without Laccase (Quantified by GC and GC/MS as mg/kg Dried Pulp) ${ }^{a}$

\begin{tabular}{|c|c|c|c|c|c|c|}
\hline & control & Lac & SAD & ACS & PCA & HBT \\
\hline $\begin{array}{l}\text { total free sterols } \\
\text { sitosterol (I) } \\
\text { stigmastanol (II) } \\
\text { fucosterol (III) }\end{array}$ & $\begin{array}{r}273 \\
222 \\
42 \\
9\end{array}$ & $\begin{array}{r}280 \\
226 \\
44 \\
10\end{array}$ & $\begin{array}{r}25 \\
19 \\
4 \\
2\end{array}$ & $\begin{array}{r}113 \\
83 \\
25 \\
5\end{array}$ & $\begin{array}{r}230 \\
186 \\
37 \\
7\end{array}$ & $\begin{array}{r}27 \\
14 \\
12 \\
1\end{array}$ \\
\hline $\begin{array}{l}\text { total oxidized sterols } \\
\text { stigmastan-3-one (IV) } \\
\text { stigmasta-3,5-dien-7-one (V) } \\
7 \alpha \text {-hydroxysitosterol (VI) } \\
7 \beta \text {-hydroxysitosterol (VII) } \\
\text { sitostanetriol (VIII) } \\
\text { 7-oxositosterol (IX) }\end{array}$ & $\begin{array}{r}32 \\
0 \\
4 \\
7 \\
12 \\
3 \\
5\end{array}$ & $\begin{array}{r}53 \\
0 \\
4 \\
13 \\
21 \\
5 \\
10\end{array}$ & $\begin{array}{l}7 \\
0 \\
2 \\
1 \\
1 \\
2 \\
1\end{array}$ & $\begin{array}{r}10 \\
1 \\
7 \\
1 \\
1 \\
0 \\
1\end{array}$ & $\begin{array}{r}43 \\
0 \\
8 \\
6 \\
9 \\
13 \\
7\end{array}$ & $\begin{array}{r}69 \\
2 \\
17 \\
8 \\
4 \\
5 \\
34\end{array}$ \\
\hline $\begin{array}{l}\text { total sterol glycosides } \\
\text { sitosteryl } 3 \beta \text {-D-glucopyranoside (X) } \\
\text { 7-oxositosteryl } 3 \beta \text {-D-glucopyranoside (XI) }\end{array}$ & $\begin{array}{r}27 \\
27 \\
0\end{array}$ & $\begin{array}{r}27 \\
27 \\
0\end{array}$ & $\begin{array}{l}2 \\
2 \\
0\end{array}$ & $\begin{array}{r}12 \\
12 \\
0\end{array}$ & $\begin{array}{r}24 \\
24 \\
0\end{array}$ & $\begin{array}{l}5 \\
2 \\
2\end{array}$ \\
\hline sterol esters (XII) & 90 & 57 & 7 & 43 & 57 & 2 \\
\hline steroid hydrocarbons (XIII) & 22 & 21 & 3 & 11 & 15 & 8 \\
\hline total steroids & 444 & 438 & 45 & 189 & 369 & 110 \\
\hline
\end{tabular}

${ }^{a}$ Lac, Laccase; SAD, syringaldehyde; ACS, acetosyringone; PCA, p-coumaric acid; HBT, 1-hydroxybenzotriazole. All standard deviations were below $8 \%$ of the mean values presented.

GC/MS of Black Liquor. Low molecular-mass compounds in the industrial black liquor from eucalypt kraft pulping were isolated by liquid-liquid extraction, and analyzed by GC/MS using an HP G1800A GCD system with a DB-5 column (30 $\mathrm{m} \times 0.25 \mathrm{~mm}$ i.d., and $0.25 \mu \mathrm{m}$ film thickness), which was programmed from $50{ }^{\circ} \mathrm{C}$ to $100{ }^{\circ} \mathrm{C}$ at $30{ }^{\circ} \mathrm{C} / \mathrm{min}$ and from $100{ }^{\circ} \mathrm{C}$ to $300{ }^{\circ} \mathrm{C}$ at $5^{\circ} \mathrm{C} / \mathrm{min}$. The final temperature was held for $20 \mathrm{~min}$. Compounds were identified by mass fragmentography, and by comparison with the Wiley and NIST libraries.

\section{Results and Discussion}

In a recent work the authors demonstrated for the first time that pitch-causing lipophilic extractives could be efficiently removed from eucalypt kraft pulp by the laccase-mediator system, using the synthetic compound HBT as a redox mediator (4). The laccase from P. cinnabarinus was selected for pulp treatment because its redox potential (around 0.75 $\mathrm{V})$ is among the highest redox potentials described for laccases $(0.4-0.8 \mathrm{~V})(15)$, high stability against temperature and mediator inactivation (16), and good results in paper pulp delignification studies (17). Several natural compounds have been suggested as laccase mediators in substitution of synthetic mediators $(6,7)$. In the present study, three ligninrelated natural phenols, namely a lignin precursor ( $p$ coumaric acid) and two lignin degradation products (syringaldehyde and acetosyringone), are investigated as an alternative to HBT in the removal of problematic pulp lipids using laccase.

Crude (unbleached) eucalypt kraft pulp was treated with $P$. cinnabarinus laccase in the presence of each of the above mediators, and subsequently bleached with hydrogen peroxide. Several controls, including pulp treated with laccase alone (without mediator), were also performed. The lipophilic compounds in the different pulps were analyzed by GC and GC/MS. The pattern of lipids in the control crude pulp after hydrogen peroxide treatment is shown in Figure 1A. The relative composition of lipids was similar to that previously reported in TCF eucalypt pulp including free sterols, steroid ketones, sterol glycosides, sterol esters, and steroid hydrocarbons (Figure 2) (4). A strong decrease of pulp lipids was found in the samples treated with laccase in the presence of both HBT (Figure 1B) and some of the phenolic mediators, as illustrated in Figure 1C for syringaldehyde, although differences in the pattern of residual lipids were observed.

The abundances of the main lipophilic compounds identified in the pulps treated with laccase and the different mediators, followed by peroxide bleaching, are listed in Table 1, compared with the treatment with laccase alone (i.e., without mediator) and the control pulp (without laccase and mediator). The results of controls with denaturized enzyme or mediator alone were the same as those obtained with the control pulp, as expected.

The GC and GC/MS analyses revealed that the treatment with laccase in the presence of $p$-coumaric acid decreased the sterol esters content by $37 \%$, including sitosteryl linoleate (compound XII in Figure 2). However, it only scarcely decreased the content of free sterols (15\%) and sterol glucosides $(10 \%)$ with respect to the control (compounds I-III and $\mathbf{X}$, respectively). The above-noted removal of esterified sterols is similar to that observed with the laccase alone, and it corresponded mostly to sterol esters of unsaturated fatty acids, which decreased preferentially over the saturated ones. Namely, the sterol esters of linoleic and oleic acids present in eucalypt pulp decreased over $80 \%$ and $70 \%$, respectively, after the laccase treatment, while the sterol esters of stearic and palmitic acids decreased over $20 \%$ and $30 \%$, respectively. This was demonstrated by isolating (using SPE) the fraction containing sterol esters from the lipophilic extract of the control pulp and the pulp treated with laccase, hydrolyzing both fractions, and determining the composition of free fatty acids by GC and GC/MS. The modification of free unsaturated fatty acids by laccases has already been reported (18). In contrast, the treatment of pulp with laccase in the presence of either syringaldehyde or acetosyringone efficiently decreased free sterols ( $91 \%$ and $59 \%$, respectively), sterol esters ( $92 \%$ and $52 \%$, respectively), and sterol glucosides ( $92 \%$ and $56 \%$, respectively). These data showed that the natural mediator syringaldehyde produces a decrease of lipophilic extractives similar to that produced by the synthetic mediator HBT. No lipid removal was achieved when the enzymatic treatment was followed by a simple alkaline extraction (under the same alkaline conditions used in the peroxide bleaching) revealing the need for a peroxide stage after the treatment with laccase and natural mediators. 


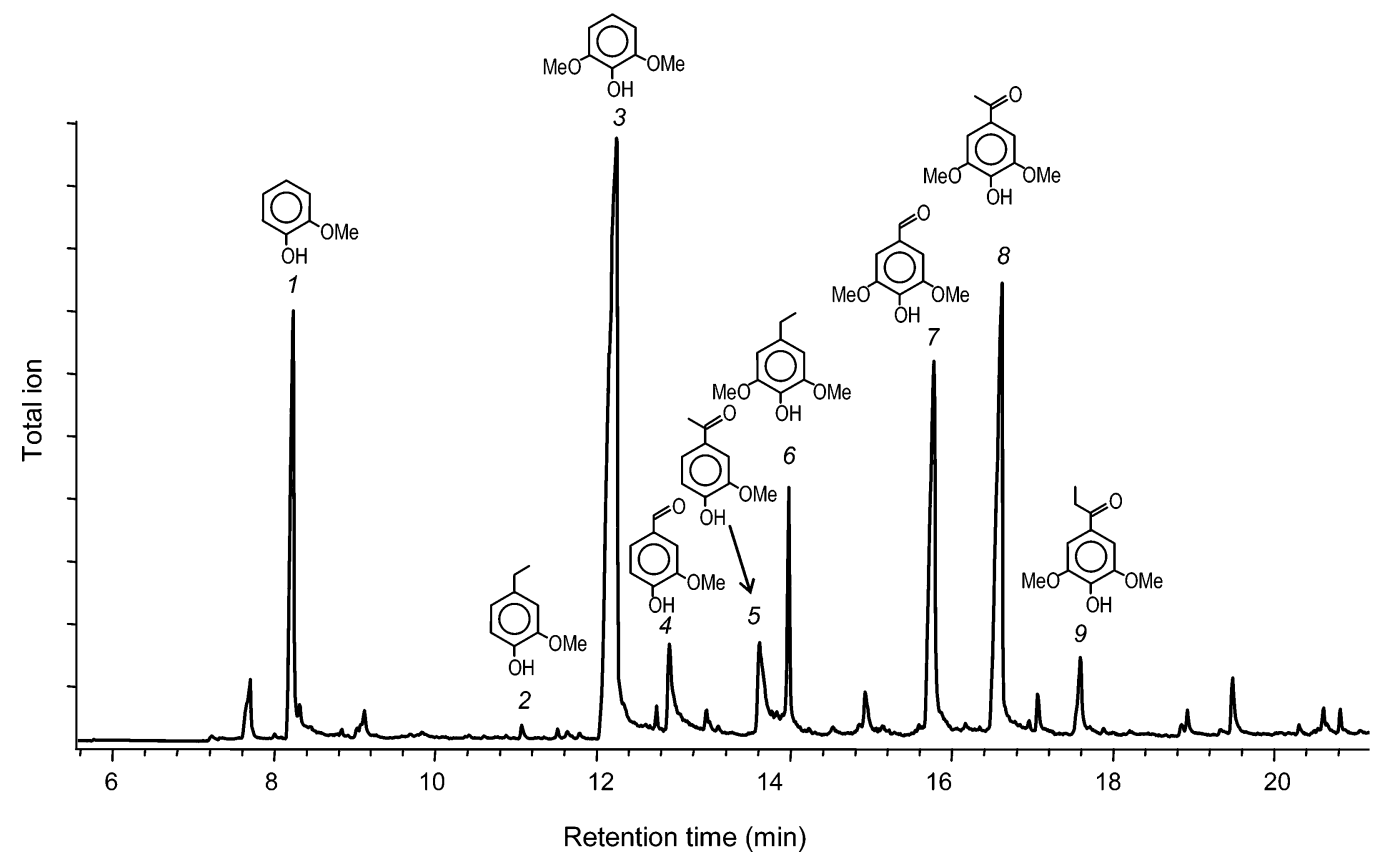

FIGURE 3. GC/MS analysis of low-molecular-mass compounds in the black liquor from kraft pulping of eucalypt wood. Main peaks: 1 , guaiacol; 2, 4-ethylguaiacol; 3, syringol; 4, vanillin; 5, acetovanillone; 6, 4-ethylsyringol; 7, syringaldehyde; 8, acetosyringone; and 9, propiosyringone.

\section{TABLE 2. Properties of Eucalypt Pulp Treated with Laccase in the Presence of Different Mediators, Followed by a $\mathrm{H}_{2} \mathrm{O}_{2}$ Stage, and Control without Laccase ${ }^{a}$

$\begin{array}{lccccc} & \text { control } & \text { SAD } & \text { ACS } & \text { PCA } & \text { HBT } \\ \text { kappa number } & 11.2 & 9.5 & 9.2 & 11.7 & 7.0 \\ \text { brightness (\% ISO) } & 56.9 & 65.7 & 65.8 & 59.1 & 73.4 \\ \text { intrinsic viscosity (mL/g) } & 1119 & 944 & 970 & 934 & 913\end{array}$

a SAD, syringaldehyde; ACS, acetosyringone; PCA, p-coumaric acid; HBT, 1-hydroxybenzotriazole.

The mechanism of such reaction is currently under investigation.

On the other hand, it was observed that the abundance of oxidized steroids originally present in the kraft pulp, namely stigmastan-3-one, stigmasta-3,5-dien-7-one, and 7-oxositosterol (compounds IV, V, and IX, respectively) arising from sitosterol oxidation, increased in the enzymatically treated pulps when using HBT as mediator, and new oxidized steroids such as 7-oxositosteryl glucopyranoside (compound XI) appeared. In contrast, when the pulp was treated with laccase in the presence of syringaldehyde, sitosterol was removed without a concomitant production of the above oxidized sterols. Moreover, those steroidal ketones initially present in eucalypt pulp also disappeared during the laccase-syringaldehyde treatment. This represents a significant advantage of the phenolic natural mediators since their use also results in removal of the recalcitrant oxidized steroids surviving after laccase-HBT treatment.

The effect of laccase treatment in the presence of phenolic mediators on some selected properties of the pulps obtained were assessed, including kappa number (a rough estimation of the lignin content in pulp), brightness, and intrinsic viscosity (an estimation of cellulose integrity), and the results were compared with those of the control pulp (Table 2). Pulps with lower kappa number and increased brightness were obtained after treatment with laccase in the presence of either syringaldehyde (1.7 points decrease of final kappa number and 8.8 points increase of final brightness with respect to the control) or acetosyringone (2.0 points decrease of kappa number and 8.9 points increase of brightness). However, the treatment with laccase in the presence of $p$-coumaric acid did not improve the eucalypt pulp properties. In fact, an increase of kappa number was observed, suggesting coupling of $p$-coumaric acid radicals on pulp lignin. Syringaldehyde and acetosyringone radicals were not involved in coupling reactions because of the presence of two methoxyl groups at $\mathrm{C}_{3}$ and $\mathrm{C}_{5}$ positions of the aromatic ring (and absence of a side-chain conjugated double bond). Therefore, the differences observed in pulp lipid (and lignin) removal by these three phenolic compounds seem inversely related to the tendency of their phenoxy radicals to undergo coupling reactions, decreasing the free radical half-life.

Although the improvement of pulp properties using syringaldehyde and acetosyringone as laccase mediators were lower than obtained using laccase-HBT, the results shown confirmed the capabilities of these natural mediators for delignifying and bleaching eucalypt kraft pulp (19). A loss of pulp viscosity was found after all the enzymatic treatments; however, those produced when using the natural mediators were lower than those caused by laccase-HBT. Similarly to the lipid removal, no improvement of pulp properties were observed when the enzymatic treatment was followed by a simple alkaline extraction revealing again the need of a peroxide treatment after treating pulp with laccase and natural mediators. The papermaking properties of pulps were not analyzed, but results from previous studies on laccasemediator removal of pulp lipids (4) showed no detrimental effects. Moreover, an increase of paper porosity, a desirable property for some paper pulps, is expected after lipid removal.

HBT belongs to the group of $-\mathrm{N}(\mathrm{OH})$ - compounds that includes the most efficient laccase mediators described till now for paper pulp delignification and bleaching (20). However, several issues remain to be solved before the industrial implementation of these laccase-mediator systems. One of the drawbacks is the cost of the synthetic mediators, which, in principle is difficult to lower enough for economic application. Another obstacle is related with the possible toxicity of some of the most powerful laccase mediators, such as the $-\mathrm{N}(\mathrm{OH})$ - compounds or their reaction products. Two of the natural phenolic mediators used in the present study, namely syringaldehyde and acetosyringone, are as 
efficient as HBT at removing sterols from paper pulp. These two phenolic compounds are potentially cheap, since they are among the main low-molecular-mass compounds extractable from black liquors of kraft pulping of eucalypt wood, where they represent together more than $30 \%$ of the hexaneacetone extract analyzed by GC/MS (Figure 3). Therefore, black liquors from kraft pulping of eucalypt (and probably also from other hardwoods) could be fractionated in such a way as to obtain a fraction rich in syringaldehyde and acetosyringone that could act together as laccase mediators in pulp treatment. These two phenolic compounds are also present in effluent waters from other pulping processes (21). Moreover, their use in pulp treatment should not cause environmental concerns since they are already present in the process, due to recycling of pulp washing waters, and they are not associated with toxicity. In fact, lignin-derived aromatic aldehydes are commercial flavoring agents for food use.

It can be concluded that some lignin-derived phenols can be used as efficient alternative redox mediators in the enzymatic treatment of paper pulps with laccase. In this way, the simultaneous removal of residual lignin responsible for pulp color and color reversion, and lipids causing important economic losses due to the formation of detrimental pitch deposits, can be achieved. Laccase-mediator treatments can be successfully integrated in an industrial-type sequence for TCF bleaching of eucalypt pulp, as it has been recently reported (22).

\section{Acknowledgments}

This study has been funded by ENCE-CSIC contracts, the Spanish projects AGL2005-01748 and BIO2005-2224, the CSIC project 2006-4-0I-039, and the EU contract NMP2-CT-2006026456. Marcel Asther (INRA, Marseille, France) is acknowledged for the P. cinnabarinus strain, and Beldem (Andenne, Belgium) is acknowledged for laccase production. D.I., J.R., and S.M. thank the Spanish CSIC for two I3P fellowships and an I3P contract, respectively, and S.C. thanks the Spanish MEC for a R\&C contract.

\section{Literature Cited}

(1) Back, E. L.; Allen, L. H. Pitch Control, Wood Resin and Deresination; TAPPI Press: Atlanta, GA, 2000.

(2) Gutiérrez, A.; del Río, J. C.; Martínez, M. J.; Martínez, A. T. The biotechnological control of pitch in paper pulp manufacturing. Trends Biotechnol. 2001, 19, 340-348.

(3) Fujita, Y.; Awaji, H.; Taneda, H.; Matsukura, M.; Hata, K.; Shimoto, H.; Sharyo, M.; Sakaguchi, H.; Gibson, K. Recent advances in enzymic pitch control. Tappi J. 1992, 75 (4), 117122.

(4) Gutiérrez, A.; del Río, J. C.; Ibarra, D.; Rencoret, J.; Romero, J.; Speranza, M.; Camarero, S.; Martínez, M. J.; Martínez, A. T. Enzymatic removal of free and conjugated sterols forming pitch deposits in environmentally sound bleaching of eucalypt paper pulp. Environ. Sci. Technol. 2006, 40, 3416-3422.

(5) Gutiérrez, A.; del Río, J. C.; Rencoret, J.; Ibarra, D.; Martínez, A. T. Main lipophilic extractives in different paper pulp types can be removed using the laccase-mediator system. Appl. Microbiol. Biotechnol. 2006, 72, 845-851.

(6) Camarero, S.; Ibarra, D.; Martínez, M. J.; Martínez, A. T. Ligninderived compounds as efficient laccase mediators for decol- orization of different types of recalcitrant dyes. Appl. Environ. Microbiol. 2005, 71, 1775-1784.

(7) Johannes, C.; Majcherczyk, A. Natural mediators in the oxidation of polycyclic aromatic hydrocarbons by laccase mediator systems. Appl. Environ. Microbiol. 2000, 66, 524-528.

(8) Herpoël, I.; Moukha, S.; Lesage-Meessen, L.; Sigoillot, J. C.; Asther, M. Selection of Pycnoporus cinnabarinus strains for laccase production. FEMS Microbiol. Lett. 2000, 9190, 1-6.

(9) Lomascolo, A.; Record, E.; Herpoël-Gimbert, I.; Delattre, M.; Robert, J. L.; Georis, J.; Dauvrin, T.; Sigoillot, J.-C.; Asther, M. Overproduction of laccase by a monokaryotic strain of $P y c$ noporus cinnabarinus using ethanol as inducer. J. Appl. Microbiol. 2003, 94, 618-624.

(10) Sigoillot, J. C.; Herpoël, I.; Frasse, P.; Moukha, S.; LesageMeessen, L.; Asther, M. Laccase production by a monokaryotic strain of Pycnoporus cinnabarinus derived from a dikaryotic strain. World J. Microbiol. Biotechnol. 1999, 15, 481-484.

(11) Gutiérrez, A.; Romero, J.; del Río, J. C. Lipophilic extractives from Eucalyptus globulus pulp during kraft cooking followed by TCF and ECF bleaching. Holzforschung 2001, 55, 260-264.

(12) Gutiérrez, A.; del Río, J. C.; Martínez, A. T. Chemical analysis and biological removal of wood lipids forming pitch deposits in paper pulp manufacturing. In Protocols in Environmental Microbiology; Spencer, J. F. T., Ed.; Humana Press: Totowa, NJ, 2004.

(13) Gutiérrez, A.; del Río, J. C.; González-Vila, F. J.; Martín, F. Analysis of lipophilic extractives from wood and pitch deposits by solidphase extraction and gas chromatography. J. Chromatogr. 1998, $823,449-455$.

(14) International Organisation for Standardization Documentation and Information (ISO). ISO Standards Collection on CD-ROM: Paper, Board and Pulps; ISO: Geneva, 2003.

(15) Li, K. C.; Xu, F.; Eriksson, K. E. L. Comparison of fungal laccases and redox mediators in oxidation of a nonphenolic lignin model compound. Appl. Environ. Microbiol. 1999, 65, 2654-2660.

(16) Ibarra, D.: Romero, J.; Martínez, M. J.; Martínez, A. T.; Camarero, S. Exploring the enzymatic parameters for optimal delignification of eucalypt pulp by laccase-mediator. Enzyme Microb. Technol. 2006, 39, 1319-1327.

(17) Sigoillot, C.; Camarero, S.; Vidal, T.; Record, E.; Asther, M.; PérezBoada, M.; Martínez, M. J.; Sigoillot, J.-C.; Asther, M.; Colom, J.; Martínez, A. T. Comparison of different fungal enzymes for bleaching high-quality paper pulps. J. Biotechnol. 2005, 115, $333-343$

(18) Karlsson, S.; Holmbom, B.; Spetz, P.; Mustranta, A.; Buchert, J. Reactivity of Trametes laccases with fatty and resin acids. Appl. Microbiol. Biotechnol. 2001, 55, 317-320.

(19) Camarero, S.; Ibarra, D.; Martínez, A. T.; Romero, J.; Gutiérrez, A.; del Río, J. C. Paper pulp delignification using laccase and natural mediators. Enzyme Microb. Technol. 2007, 40, 12641271.

(20) Xu, F.; Deussen, H. J.; Lopez, B.; Lam, L.; Li, K. Enzymatic and electrochemical oxidation of N-hydroxy compounds. Redox potential, electron-transfer kinetics, and radical stability. Eur. J. Biochem. 2001, 268, 4169-4176.

(21) Ismail, F.; Mulholland, D. A.; Marsh, J. J. An analysis of the water soluble components of Sappi Saiccor's effluent streams. Water SA 2005, 31, 569-574.

(22) Ibarra, D.; Camarero, S.; Romero, J.; Martínez, M. J.; Martínez, A. T. Integrating laccase-mediator treatment into an industrialtype sequence for totally chlorine free bleaching eucalypt kraft pulp. J. Chem. Technol. Biotechnol. 2006, 81, 1159-1165.

Received for review November 14, 2006. Revised manuscript received March 2, 2007. Accepted March 26, 2007.

ES062723+ 